University of Nebraska - Lincoln

DigitalCommons@University of Nebraska - Lincoln

Faculty Publications: Department of

Entomology

Entomology, Department of

2019

P7 and P8 proteins of High Plains wheat mosaic virus, a negativestrand RNA virus, employ distinct mechanisms of RNA silencing suppression

\author{
Adarsh K. Gupta \\ Texas A\&M University, adarsh.bio@gmail.com \\ Gary L. Hein \\ University of Nebraska - Lincoln, ghein1@unl.edu \\ Satyanarayana Tatineni \\ USDA-ARS, Satyanarayana.Tatineni@ars.usda.gov
}

Follow this and additional works at: https://digitalcommons.unl.edu/entomologyfacpub

Part of the Entomology Commons

Gupta, Adarsh K.; Hein, Gary L.; and Tatineni, Satyanarayana, "P7 and P8 proteins of High Plains wheat mosaic virus, a negative-strand RNA virus, employ distinct mechanisms of RNA silencing suppression" (2019). Faculty Publications: Department of Entomology. 800.

https://digitalcommons.unl.edu/entomologyfacpub/800

This Article is brought to you for free and open access by the Entomology, Department of at DigitalCommons@University of Nebraska - Lincoln. It has been accepted for inclusion in Faculty Publications: Department of Entomology by an authorized administrator of DigitalCommons@University of Nebraska - Lincoln. 


\title{
P7 and P8 proteins of High Plains wheat mosaic virus, a negative-strand RNA virus, employ distinct mechanisms of RNA silencing suppression
}

\author{
Adarsh K. Gupta $^{\mathrm{a}, 1}$, Gary L. Hein ${ }^{\mathrm{b}}$, Satyanarayana Tatineni ${ }^{\mathrm{c}, *}$

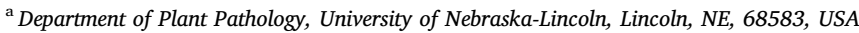 \\ ${ }^{\mathrm{b}}$ Department of Entomology, University of Nebraska-Lincoln, Lincoln, NE, 68583, USA \\ ${ }^{\mathrm{c}}$ United States Department of Agriculture-Agricultural Research Service and Department of Plant Pathology, University of Nebraska-Lincoln, Lincoln, NE, 68583, USA
}

\section{A B S T R A C T}

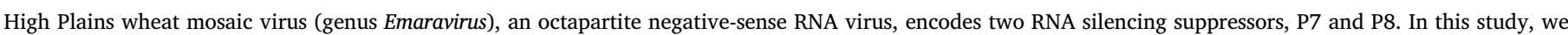

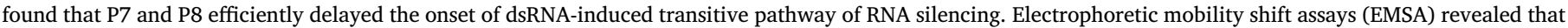

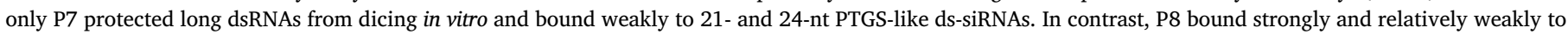

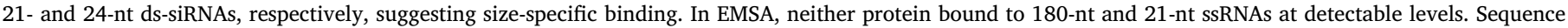

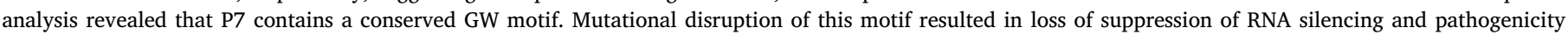

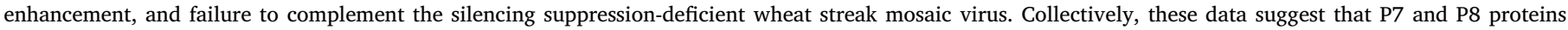
utilize distinct mechanisms to overcome host RNA silencing for successful establishment of systemic infection in planta.

\section{Introduction}

RNA silencing is a conserved eukaryotic gene regulation mechanism that provides sequence-specific antiviral defense in higher plants and a few taxa of invertebrates (Baulcombe, 2004; Covey et al., 1997; Ding et al., 2004; Ratcliff et al., 1997). Double-stranded RNA (dsRNA) molecules trigger Dicer-like (DCL) Class-III RNases in the host cytoplasm that result in hydrolysis of dsRNAs into small 21-24 nt RNA duplexes, typically with 2-nt $3^{\prime}$ overhangs (Ding and Voinnet, 2007; Fire et al., 1998; Hamilton and Baulcombe, 1999; Ketting et al., 2001). The 3' overhangs of ds-siRNAs are 2'-O-methylated by HEN1 to stabilize and protect them from further hydrolysis by exonucleases (Yang et al., 2006). These modified 3 ' overhangs are recognized by the PAZ domain of the silencing effector protein Argonaute (AGO; Lingel et al., 2003; Tian et al., 2011). This induces ATP-dependent conformational changes aided by HSP90 and HCP70 chaperones (Iwasaki et al., 2010) that are crucial for incorporating nascent siRNA duplex onto AGO for the formation of the RNA-induced silencing complex (RISC; Liu et al., 2006; Rivas et al., 2005). Based on the thermodynamic stability of the overhangs, one of the strands is unwound from the siRNA duplex (Schwarz et al., 2003). Guided by siRNA, RISC surveils the cytoplasm for complementary viral RNA targets and cleaves them by PIWI-domain mediated hydrolysis (Rand et al., 2005; Song et al., 2004), rendering antiviral defense through post-transcriptional gene silencing (PTGS).

Additionally, RNA dependent RNA polymerases (RDRs) extend the open 3' termini of RISC-independently annealed siRNA to synthesize cRNA for generating dsRNAs. These dsRNAs are available for further dicing and production of transitive or secondary siRNAs (Parent et al., 2015; Sijen et al., 2001). The importance of the transitive pathway of RNA silencing lies in the mobile nature of siRNAs through cell-to-cell and systemic trails via plasmodesmata and phloem companion cells, respectively (Melnyk et al., 2011). This imparts antiviral immunity to uninfected tissues. However, viruses evolved to counter the effects of RNA silencing by encoding viral suppressor(s) of RNA silencing (VSR) (Csorba et al., 2015; Ding and Voinnet, 2007; Li and Ding, 2006). VSRs are crucial for successful replication of virus and enable long-distance spread and accumulation to the level required to establish pathogenicity (Cronin et al., 1995; Ding et al., 1995; Lakatos et al., 2004). To overcome host defense, VSRs target the key players of both RNA silencing elicitors, such as single- (ss) or double-stranded (ds) RNAs, and

\footnotetext{
* Corresponding author.

E-mail address: satyanarayana.tatineni@ars.usda.gov (S. Tatineni).

${ }^{1}$ Present address: Department of Entomology, Texas A\&M University, College Station, TX 77843.
} 
host proteins that are involved in the RNA silencing pathway. For example, several VSRs were shown to have affinity for long and short dsRNAs in a size-independent manner (Lingel et al., 2005; Mérai et al., 2005, 2006; Schnettler et al., 2010). However, a few other VSRs selectively sequester only PTGS-generated short dsRNAs (ds-siRNAs) (Chen et al., 2008; Diaz-Pendon et al., 2007; Dunoyer et al., 2001; Reed et al., 2003; Silhavy et al., 2002). VSRs reported from different groups of viruses have highly divergent sequences, but they have conserved targets in the RNA silencing pathway, suggesting the convergent evolution of suppressors of RNA silencing proteins (Berry et al., 2009).

Several VSRs are reported to interact with proteinaceous components of RNA silencing. For example, P1 of rice yellow mottle virus blocks DCL4 to inhibit the generation of siRNAs (Lacombe et al., 2010). P126 of tobacco mosaic virus or HC-Pro protein of zucchini yellow mosaic virus were shown to inhibit the activity of HEN1 (Jamous et al., 2011; Vogler et al., 2007). VSRs of diverse groups of viruses were shown to interact with AGO to prevent different stages of RISC formation and function (Chiu et al., 2010; Csorba et al., 2010; Giner et al., 2010; Iki et al., 2017). Rice yellow stunt virus (RYSV) encoded P6 was found to interact with RDR6 to interrupt production of secondary siRNAs (Guo et al., 2013).

Generally, RNA viruses encode a single protein with RNA silencing suppressor activity. However, a few viruses were shown to encode multiple VSRs. For example, tomato chlorosis virus encodes three proteins with VSR function: coat protein (CP), minor coat protein and dsRNA-binding P22 (Cañizares et al., 2008; Landeo-Ríos et al., 2016). CP, P20, and P23 of citrus tristeza virus were shown to independently suppress different levels of RNA silencing (Lu et al., 2004). Red clover necrotic mosaic virus possesses viral replication complex and movement protein for suppression of host RNA silencing (Powers et al., 2008; Takeda et al., 2005). The Tat protein of human immunodeficiency virus-1 (HIV-1) was shown to counteract RNA silencing through dsRNA binding (Qian et al., 2009). In addition, the HIV-1 encoded Nef protein was shown to counter the miRNA induced silencing complex (miRISC) via AGO2 interaction (Aqil et al., 2013). The scenarios of viruses encoding multiple VSRs as well as VSRs with multiple targets, suggest efficient approaches from the viral perspective. It also underscores the importance of suppressing RNA silencing for successful completion of the viral life-cycle and establishment of systemic infection.

Compared with positive-sense RNA viruses, mechanisms of VSRs encoded by negative-sense RNA viruses have not been extensively studied. NS3, a strong silencing suppressor of rice hoja blanca virus (genus Tenuivirus; family Phenuiviridae) possesses weak siRNA binding affinity through its putative dsRNA-binding domain (dsRBD, Yang et al., 2011). P3 of rice stripe virus (genus Tenuivirus; family Phenuiviridae) bound specifically to ds-siRNA but not long dsRNA (Xiong et al., 2009). P6 of RYSV was shown to affect RDR6-mediated secondary siRNA synthesis (Guo et al., 2013). Lettuce necrotic yellows virus (genus Cytorhabdovirus; family Rhabdoviridae) encoded phosphoprotein $P$ shows remarkable suppressor activity in plants but not in insect cells (Mann et al., 2015), and interacts with several players of RNA silencing such as AGO1, AGO2, AGO4, RDR6, and SGS3 (Mann et al., 2016).

Recently, we reported that the octapartite negative-sense RNA genome of High Plains wheat mosaic virus (HPWMoV), an Emaravirus in the family Fimoviridae (Tatineni et al., 2014), encodes two suppressors of RNA silencing (Gupta et al., 2018). The P7 and P8 proteins of HPWMoV independently suppressed RNA silencing induced locally by ss or ds RNAs and systemic silencing induced by ssRNA of the GFPreporter in $N$. benthamiana. We also showed that P7 or P8 rescue VSRdeficient wheat streak mosaic virus (WSMV) in wheat and found that heterologous potato virus X (PVX) showed enhanced pathogenicity in the presence of P7 or P8 (Gupta et al., 2018). In this report, we analyzed several mechanistic approaches to identify the mode of action with which P7 and P8 suppress the host RNA silencing. We showed that HPWMoV P7 binds to dsRNAs with no size specificity and protects long dsRNA from Dicer activity, while P8 binds size-specifically only to PTGS-like small ds-siRNA. P7 contains a conserved GW motif, and disruption of this motif resulted in loss of suppression of ssRNA-induced local silencing, ability to enhance PVX virulence and ability to rescue VSR-deficient WSMV-GFP- $\triangle \mathrm{P} 1$. This study revealed that the two RNA silencing suppressors of HPWMoV, negative-strand ssRNA virus, utilize distinct mechanisms with division of labor for the suppression of RNA silencing.

\section{Materials and methods}

\subsection{Preparation of constructs}

Plasmid DNA of pCASS4-P7 or -P8 (Gupta et al., 2018) was used as a template for PCR amplifications. The P7 or P8 ORF was engineered in pMAL-c5X between the NdeI and NotI restriction enzyme sites, and chemically transformed into a NEB express strain of Escherichia coli (New England Biolabs Inc., Ipswich, MA). Site-directed W219A mutagenesis of P7 was accomplished by overlap extension PCR with primers H-143 (5'-GATGATGAATATTCCA CTGGCGCATTTGGTGACAAACATA TTG-3') and its reverse complement H-144.

Chimeric PVX-P7-W219A was generated by cloning P7-W219A sequence between the ClaI and AscI restriction sites of a PVX infectious clone (pP2C2S-PVX; Chapman et al., 1992). The P7-W219A-GFP sequence was tailored by fusing P7-W219A cistron upstream to the GFP sequence with an intervening 11-amino acid cleavage peptide of WSMV NIa-Pro. The P1 cistron of an infectious cDNA clone of WSMV isolate Sidney 81 (pSP6-WSMV; Choi et al., 1999) was replaced with the P7W219A-GFP sequence to generate pWSMV-GFP- $\triangle$ P1-P7-W219A. All PCR reactions were performed with Herculase II Fusion DNA polymerase (Agilent Technologies, Santa Clara, CA). Sequences of all constructs were verified on Applied Biosystems 3730xl DNA Analyzer at the University of Florida ICBR Core DNA sequencing facility.

\subsection{Electrophoretic mobility shift assay (EMSA)}

Recombinant maltose binding protein (MBP)-tagged P7 (MBP:P7) or P8 (MBP:P8) was expressed in E. coli through pMAL-c5X, followed by affinity chromatography purification using amylose resin (New England Biolabs) and eluted in sterile PBS (pH 7.4). Purified protein was quantified by using the Bradford assay (Bio-Rad) and stored at $4{ }^{\circ} \mathrm{C}$ for further analysis. Synthetic PTGS-like ds-siRNAs (21 or $24 \mathrm{nt}$ ) with 2-nt $3^{\prime}$ overhangs were prepared by annealing chemically synthesized 5'PssRNA (Integrated DNA Technologies, Skokie, IL) in $20 \mathrm{mM}$ Tris- $\mathrm{HCl}$ (pH 8.0), 1 mM EDTA and $50 \mathrm{mM} \mathrm{NaCl}$ (TEN buffer). Long dsRNA was prepared by annealing complementary strands of ssRNA transcribed in vitro from DNA templates derived from GFP (180-nt) or HPWMoV P2a (675-nt; GenBank accession number KJ939624) sequences in TEN buffer containing $0.02 \%$ Tween 20 (TEN-T buffer). RNA-protein interaction experiments were conducted at room temperature by incubating $100 \mathrm{ng}$ of 180-nt dsRNA or $50 \mathrm{ng} 21$ - and 24-nt ds-siRNAs with MBPtagged P7 or P8 in $30 \mu \mathrm{l}$ reactions for $30 \mathrm{~min}$. Interaction between protein-RNA was analyzed through $4-12 \%$ non-denaturing PAGE in 1XTBE (Tris-borate-EDTA) at $4{ }^{\circ} \mathrm{C}$ and visualized by SYBR Green gel staining (Thermo Scientific, Waltham, MA) as described in Samuel et al. 
(2016). The percentage of bound dsRNA was determined by quantifying fluorescence of the unbound dsRNA band using ImageJ software (Schneider et al., 2012) and computing the difference from the amount loaded. The affinity curves were generated by plotting the amount of protein loaded against the percentage of dsRNA binding to proteins (Heffler et al., 2012).

\subsection{Dicer protection assay}

A PCR amplified full-length fragment of HPWMoV P2a was used as a template for in vitro transcription to generate positive- and negativestrand RNA, followed by annealing to generate 675-nt dsRNA. In vitro dicing reactions were performed by incubating $1.0 \mu \mathrm{g}$ of 675 -nt dsRNA with recombinant human Dicer (0.5 U; Genlantis, San Diego CA) supplemented with $0.35 \mathrm{nmol}$ of MBP:P7 or MBP:P8 in a $30 \mu 1$ reaction at $37^{\circ} \mathrm{C}$ overnight. The dicing reaction mixture consisted of $250 \mathrm{mM} \mathrm{NaCl}$, $30 \mathrm{mM}$ HEPES ( $\mathrm{pH}$ 8.0), $0.05 \mathrm{mM}$ EDTA, $2.5 \mathrm{mM} \mathrm{MgCl}_{2}$ and $1 \mathrm{mM}$ ATP. The Dicer reaction was inactivated by adding EDTA to $10 \mathrm{mM}$ and analyzed through $4-12 \%$ non-denaturing PAGE in 1 XTBE buffer at $4{ }^{\circ} \mathrm{C}$, followed by SYBR Green staining. The MBP supplemented dicing reaction served as a control for MBP tags as well as a random protein with no dsRNA-binding properties.

\subsection{Agroinfiltrations}

Agrobacterium tumefaciens strain EHA105 was used for chemical transformation of pCASS 4 constructs. Agrobacteria harboring pCASS4 constructs were grown overnight at $28^{\circ} \mathrm{C}$ and resuspended to optical density of 1.0 at $600 \mathrm{~nm}$ in infiltration buffer $\left(10 \mathrm{mM} \mathrm{MgCl}_{2}\right.$ with $10 \mathrm{mM}$ MES, pH 5.5 and $100 \mu \mathrm{M}$ Acetosyringone), and incubated at room temperature for $3 \mathrm{~h}$. Agrosuspension was infiltrated into the lamina of fully expanded leaves of wild-type $N$. benthamiana or GFPtransgenic line $16 \mathrm{c}$ plants at the 6-8 leaf stage. Agroinfiltrated plants were maintained in a growth chamber at $24-26^{\circ} \mathrm{C}$ with a $14 \mathrm{~h}$ photoperiod. Leaves infiltrated with 35S:P7, 35S:P7-W219A or pCASS4 along with 35S:ssGFP (Qu et al., 2003) and 35S:dsGFP (Tatineni et al., 2012) were observed under long range UV light for green fluorescence at 3 and $5 \mathrm{dpa}$ and photographed through an orange filter with a Nikon D70 camera (Nikon, Melville NY). For systemic silencing studies, N. benthamiana line $16 \mathrm{c}$ plants were agroinfiltrated with $35 \mathrm{~S}: \mathrm{P} 3,35 \mathrm{~S}: \mathrm{P7}$, 35S:P8, 35S:P7 + 35S:P8 (Gupta et al., 2018) or empty pCASS4 along with 35S:ssGFP and 35S:dsGFP.

\subsection{Infection of plants with in vitro transcripts}

Linearized pPVX (pP2C2S-PVX; Chapman et al., 1992), pPVX-P7, pPVX-P7-W219A were transcribed in vitro and mechanically inoculated onto fully expanded $N$. benthamiana leaves at the 6-leaf stage. The inoculated plants were incubated at $18{ }^{\circ} \mathrm{C}$ in a growth chamber with a $16 \mathrm{~h}$ photoperiod. Total RNA was extracted using the Tripure isolation reagent (Roche) method from upper noninoculated symptomatic leaves at 21 and 28 days postinoculation (dpi). In vitro transcripts from pWSMV-GFP (pSP6-WSMV-GFP-6KI/CI; Tatineni et al., 2011), pWSMVGFP- $\Delta$ P1, pWSMV-GFP- $\Delta$ P1-P7 (Gupta et al., 2018), or pWSMV-GFP$\Delta$ P1-P7-W219A were mechanically inoculated onto wheat seedlings at the single-leaf stage, and incubated in a greenhouse at $22-27^{\circ} \mathrm{C}$ with a photoperiod of $16 \mathrm{~h}$. Inoculated leaves and upper noninoculated leaves were examined under a Zeiss Stereo Discovery V12 Fluorescence Microscope by using a narrow-band GFP filter set 38 for green fluorescence at excitation and emission ranges of $400-450 \mathrm{~nm}$ and 450 $490 \mathrm{~nm}$, respectively. Fluorescent micrographs were taken using an
AxioCam MRc5 camera mounted on the fluorescent microscope.

\subsection{Polymerase chain reaction assays}

One $\mu \mathrm{g}$ of total RNA was incubated with $25 \mathrm{ng}$ of random hexamers for reverse transcription with SuperScript III First-Strand Synthesis System (Invitrogen, Carlsbad, CA). Resultant cDNA was used as a template for PCR to examine the stability of P7 or P7-W219A ORFs inserted into the PVX genome with primers Tr-206 and Tr-207 as described in Gupta et al. (2018). Total RNA extracted from wheat seedlings inoculated at 10 or $21 \mathrm{dpi}$, and used for random-primed reverse transcription, followed by diagnostic PCR with primers XV1 and XC1 (Tatineni et al., 2017) and confirmation of the presence of inserted sequences with W-479 and W-481 as described in Gupta et al. (2018). Total RNA extracted from PVX-WT, PVX-P7, or PVX-P7-W219A infected $N$. benthamiana leaves at 21 and 28 dpi was analyzed by real-time RTPCR (RT-qPCR) with primers G-35 and G-36 for determining fold change of PVX genomic RNA accumulation as described in Gupta et al. (2018).

\subsection{Western blots}

Leaf tissue $(200 \mathrm{mg}$ ) collected from inoculated or upper noninoculated leaves from wheat plants inoculated with WSMV-GFP, WSMV-GFP- $\Delta$ P1, WSMV-GFP- $\Delta$ P1-P7, or WSMV-GFP- $\Delta$ P1-P7-W219A was homogenized in protein extraction buffer $(1 \mathrm{ml})$ containing $50 \mathrm{mM}$ Tris acetate $\mathrm{pH}$ 7.4, $10 \mathrm{mM}$ Potassium acetate, $1 \mathrm{mM}$ EDTA and $5 \mathrm{mM}$ DTT with Protease Inhibitor cocktail (Roche). Total protein extract was separated through SDS-PAGE on 4-20\% Tris-glycine gel and immunodetected with WSMV CP polyclonal antibodies or anti-GFP monoclonal antibody (Clontech, Mountain View, CA).

\section{Results}

\subsection{P7 and P8 suppresses dsRNA-induced transitive pathway of silencing}

We previously showed that P7 and P8 of HPWMoV efficiently suppressed dsRNA-induced local silencing in $N$. benthamiana leaves (Gupta et al., 2018). Here, we examined whether P7 or P8 suppresses the dsRNA-induced transitive pathway of silencing. Agrobacterial suspension harboring pCASS4-35S:P7 or P8 along with 35S:ssGFP and 35S:dsGFP were infiltrated into the leaves of GFP-transgenic $N$. benthamiana line $16 \mathrm{c}$ at the 6-leaf stage (Fig. 1A). Green fluorescence in upper noninfiltrated leaves was silenced in all plants agroinfiltrated with HPWMoV P3 or pCASS4 by 5 dpa. Plants agroinfiltrated with P7, P8, P7 + P8 or TriMV P1 (positive control) did not show complete (100\%) suppression of dsGFP-induced silencing until 15 dpa (Fig. 1B and C). Plants infiltrated with P7 showed greater systemic silencing (23\%) compared with P8 (10\%) at 5 dpa (Fig. 1C). At 7 dpa, systemic silencing increased in P7 (77\%) and TriMV P1 (71\%) infiltrated plants, but only a slight increase in P8 infiltrated plants (41\%), suggesting that P8 efficiently delayed the onset of dsRNA-induced silencing. Plants infiltrated with $\mathrm{P} 7+\mathrm{P} 8$ constructs showed $0 \%$ systemic silencing at 5 dpa, which was increased only to $42 \%$ at 7 dpa (Fig. 1C). At $10 \mathrm{dpa}$, $87 \%$ of plants infiltrated with P7 showed systemic silencing, while 72 or $75 \%$ of them silenced systemically with P8 or P7 + P8. Taken together, these results indicate that P7 and P8 delayed the onset of dsRNA-induced transitive pathway of silencing. 
A

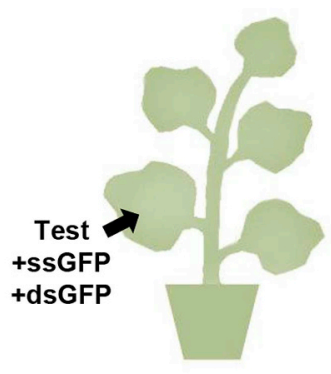

B
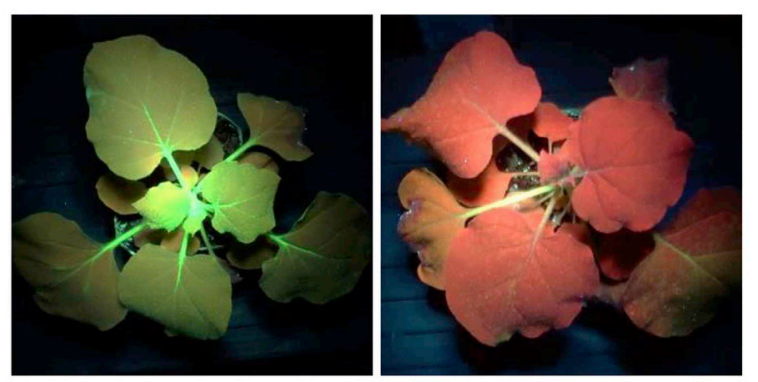

C

\begin{tabular}{|c|c|c|c|c|c|c|c|c|c|}
\hline \multirow[b]{2}{*}{$\begin{array}{c}\text { Agroinfiltrated } \\
\text { test constructs + } \\
\text { 35S:ssGFP } \\
\text { + 35S:dsGFP }\end{array}$} & \multirow[b]{2}{*}{$\begin{array}{c}\# \\
\text { Infiltrated } \\
\text { plants }\end{array}$} & \multicolumn{2}{|c|}{$5 \mathrm{dpa}$} & \multicolumn{2}{|c|}{$7 \mathrm{dpa}$} & \multicolumn{2}{|c|}{10 dpa } & \multicolumn{2}{|c|}{$15 \mathrm{dpa}$} \\
\hline & & $\begin{array}{c}\text { \# } \\
\text { Systemic } \\
\text { silenced } \\
\text { plants } \\
\end{array}$ & $\begin{array}{c}\% \\
\text { Systemic } \\
\text { silencing }\end{array}$ & $\begin{array}{c}\text { \# Systemic } \\
\text { silenced } \\
\text { plants }\end{array}$ & $\begin{array}{c}\% \\
\text { Systemic } \\
\text { silencing }\end{array}$ & $\begin{array}{c}\text { \# } \\
\text { Systemic } \\
\text { silenced } \\
\text { plants } \\
\end{array}$ & $\begin{array}{c}\% \\
\text { Systemic } \\
\text { silencing }\end{array}$ & $\begin{array}{c}\# \\
\text { Systemic } \\
\text { silenced } \\
\text { plants } \\
\end{array}$ & $\begin{array}{c}\% \\
\text { Systemic } \\
\text { silencing }\end{array}$ \\
\hline 35S:P7 & 30 & 7 & 23 & 23 & 77 & 26 & 87 & 30 & 100 \\
\hline 35S:P8 & 29 & 3 & 10 & 12 & 41 & 21 & 72 & 29 & 100 \\
\hline 35S:P7+35S:P8 & 12 & 0 & 0 & 5 & 42 & 9 & 75 & 12 & 100 \\
\hline 35S:P3 & 13 & 13 & 100 & 13 & 100 & 13 & 100 & 13 & 100 \\
\hline pCASS4 & 30 & 30 & 100 & 30 & 100 & 30 & 100 & 30 & 100 \\
\hline 35S:TriMV P1 & 17 & 2 & 12 & 12 & 71 & 14 & 82 & 17 & 100 \\
\hline
\end{tabular}

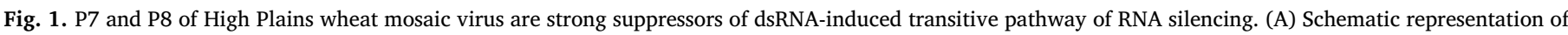

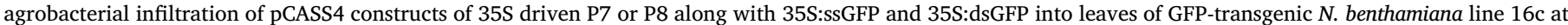

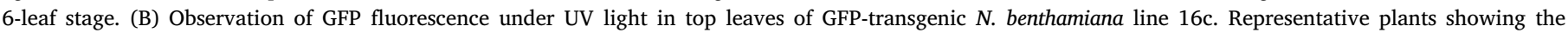

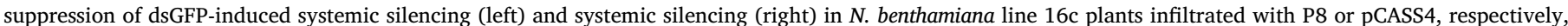

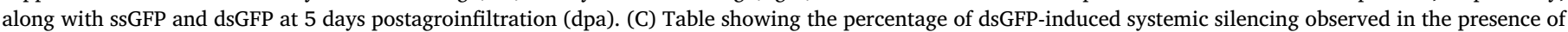

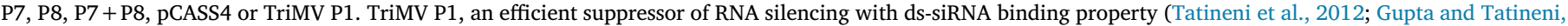
2019b) and pCASS4 were used as positive and negative controls, respectively.

\subsection{HPWMoV P7 and P8 sequesters ds-siRNAs but only P7 binds to long dsRNA}

Proteins encoded by HPWMoV RNAs 7 (P7) and 8 (P8) were identified as suppressors of RNA silencing (Gupta et al., 2018), but mechanistics of these proteins in suppression of RNA silencing are not known. To test if these two HPWMoV-encoded suppressors independently possess affinity to dsRNAs, recombinant MBP-tagged P7 or P8 proteins were expressed in E. coli (Fig. 2A), followed by electrophoretic mobility shift assay. MBP:P7 or MBP:P8 were incubated with long dsRNA (180 nt) or ds-siRNAs (21- and 24-nt) and analyzed by nondenaturing PAGE and SYBR Green gel staining. The P7 protein formed complexes with long dsRNA while no detectable complexes found with P8, as revealed in EMSA (Fig. 2B, lanes 1 and 2). These data revealed that the P7 protein bound to long dsRNA with high affinity, while P8 did not. However, neither P7 nor P8 bound to long ssRNA as no detectable affinity was observed in EMSA (Fig. 2B, compare lanes 5 and 6 with lanes 7 and 8).

Next, the affinity of P7 and P8 toward the PTGS-like ds-siRNAs was examined by using 21- and 24-nt ds-siRNAs in EMSA, and found that both the P7 and P8 proteins showed affinity toward PTGS-like dssiRNAs (Fig. 2C, lanes 1 and 2). However, the P8 protein interacted strongly with 21- and 24-nt ds-siRNAs with high affinity compared with that of P7 (Fig. 2C, compare lanes 1 and 2). The P7 or P8 proteins showed no detectable interaction with 21-nt ssRNA (Fig. 2C).

Affinity of P7 toward long dsRNA species, and P7 and P8 toward dssiRNAs was further analyzed by titrating standard amounts of 180-nt long dsRNA (100 ng) and 21- and 24-nt ds-siRNAs (50 ng each), respectively, with the two-fold serially diluted protein samples (Fig. 2D-F). In EMSA, fluorescence of the RNA-only lane containing unbound dsRNA or ds-siRNAs was considered as $100 \%$. Based on the unbound dsRNA in each lane, percentages of dsRNA binding against the amount of P7 or P8 loaded were plotted to generate affinity curves. The skewness of the binding curve of a protein represents higher affinity toward particular dsRNA species (Bisswanger, 2014). The binding kinetics revealed that $\sim 0.2 \mathrm{nmol}$ of MBP:P7 was required to bind $50 \%$ of 180-nt dsRNA as well as 21- and 24-nt ds-siRNAs (Fig. 2D and E). In contrast, MBP:P8 displayed differential binding preference to ds-siRNAs with $\sim 0.2$ and $\sim 0.05 \mathrm{nmol}$ of P8 was required to bind $50 \%$ of 24 - and 21-nt ds-siRNAs, respectively (Fig. 2F). These data revealed that P8 exhibited higher affinity toward 21-nt compared with 24-nt ds-siRNAs. Binding kinetics also suggest that P7 has affinity toward dsRNAs with no size preference. In contrast, P8 has no detectable affinity toward long dsRNA (180 nt) but has higher and size-specific differential affinity toward 21- and 24-nt ds-siRNAs. 
A

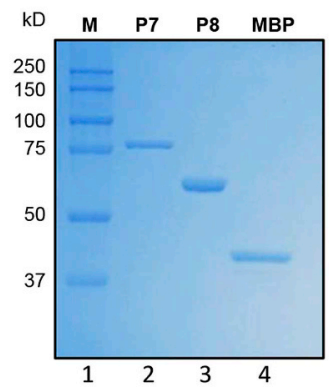

B

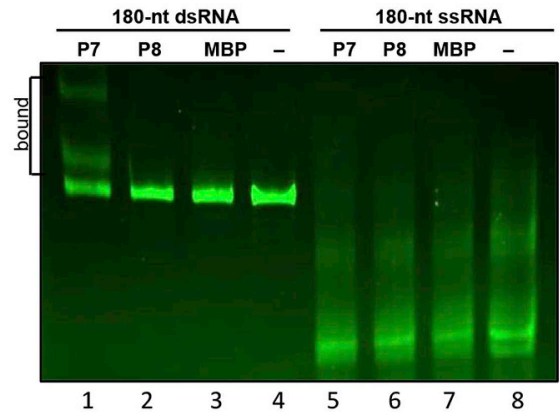

C

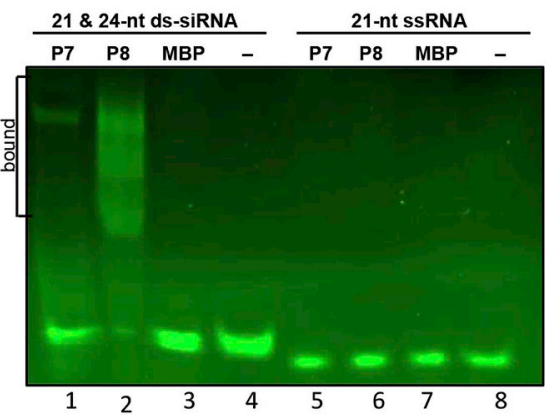

D

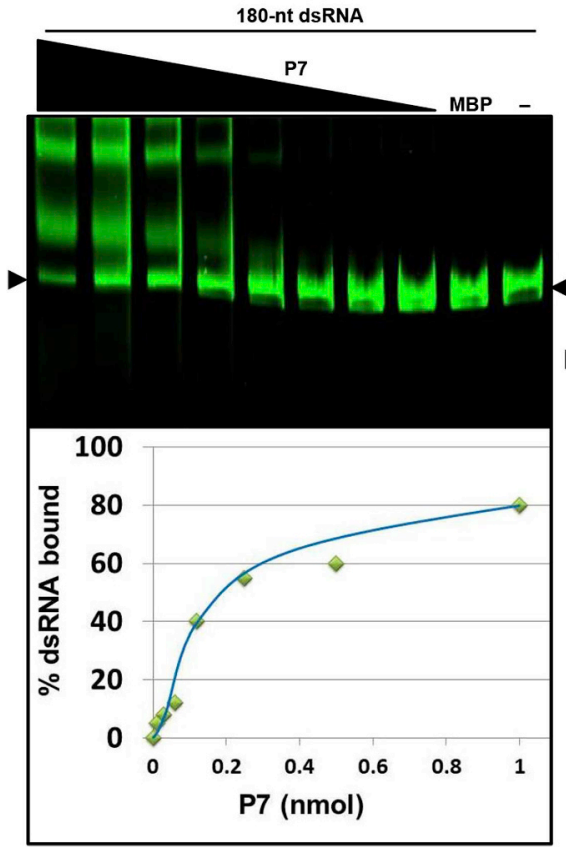

E

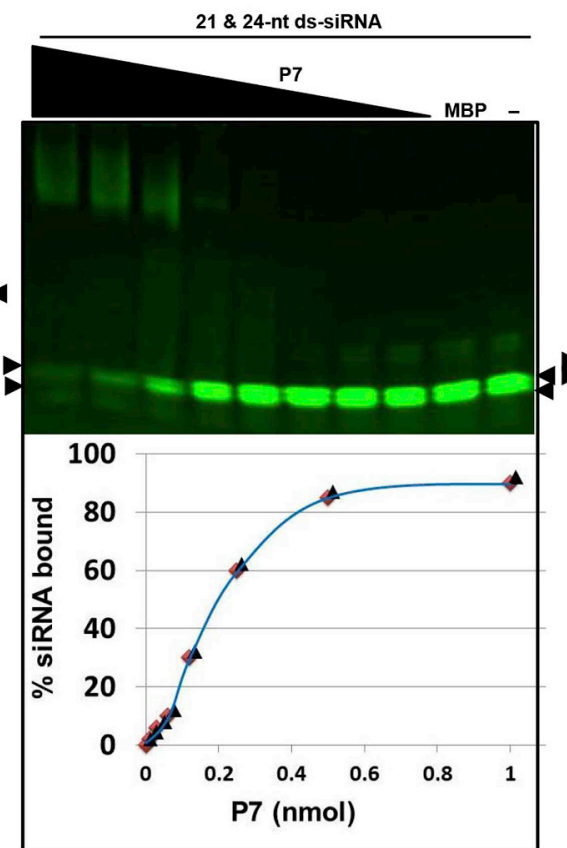

$\mathbf{F}$

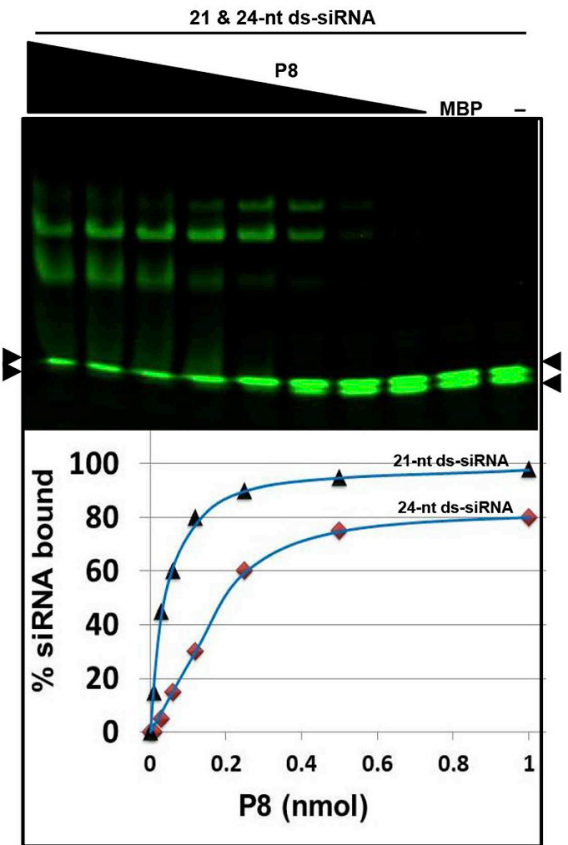

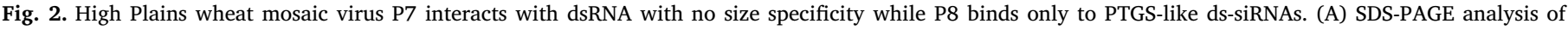

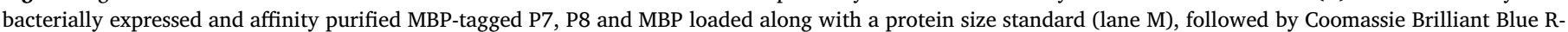

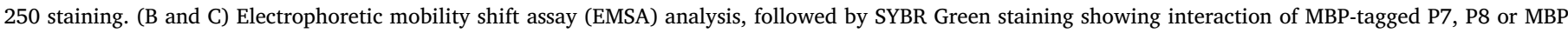

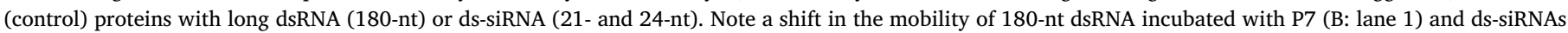

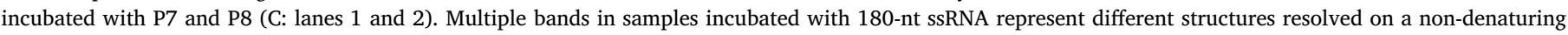

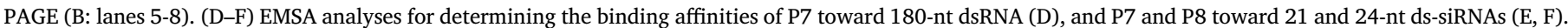

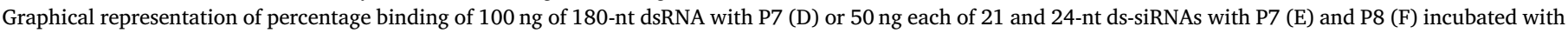

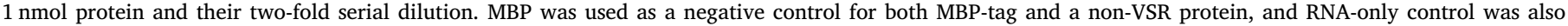
included in all EMSA analyses. Bands used for quantification of unbound dsRNA using ImageJ software in D-F are indicated with arrowheads.

\subsection{HPWMoV P7 but not P8 interferes with Dicer activity}

The significance of dsRNA binding property of P7 and P8 was examined by performing in vitro dicing reactions with the human Dicer enzyme. Though EMSA analyses showed that P7 but not P8 possess long dsRNA binding property, both of these proteins were tested for the dsRNA protection against dicing. In vitro dicing reaction of 675-nt dsRNA with recombinant human Dicer in the presence of P7 or P8 was performed, followed by non-denaturing PAGE and SYBR Green staining. The results presented in Fig. 3 suggested that Dicer reaction in the presence of P7 showed significant reduction in siRNA accumulation (lane 1). In addition to protection of dsRNA, interaction of dsRNA with P7 showed an electrophoretic mobility shift (Fig. 3, lane 1). As expected, P8 or MBP did not inhibit siRNA production in in vitro dicing reaction (Fig. 3, lanes 2 and 3). These data indicated that HPWMoV P7 but not P8 binds to long dsRNA and protects against dicing. 


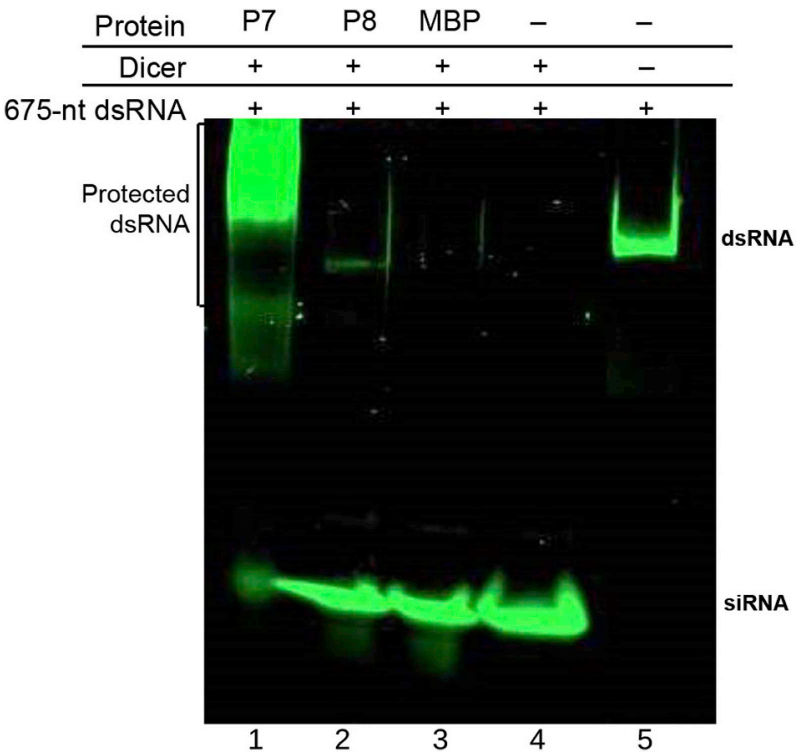

Fig. 3. High Plains wheat mosaic virus P7 binds to dsRNA and interferes with Dicer activity. Dicer protection assay was performed in a dicing reaction on a 675-nt dsRNA with recombinant human Dicer supplemented with MBP-tagged P7, P8, MBP or dicing buffer. Dicer reaction was incubated overnight, followed by non-denaturing PAGE analysis and SYBR Green staining. Note P7 supplemented dicing reaction resulted in drastic reduction in siRNA accumulation (lane 1), while P8 (lane 2) or MBP (lane 3) supplemented reactions were similar to no protein dicing reaction (lane 4). MBP was used as a negative control for MBP tags as well as an unrelated and non-VSR protein control. $100 \mathrm{ng}$ of dsRNA-only control was included to represent negative control of dicing reaction (lane 5).

\section{A}

HPWMOV-P7_NC_029554.1

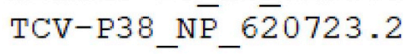

\section{B}

HPWMOV-P7 NC 029554.1 TriMV-P1 $\bar{Y} P \quad \overline{0} 02956088$ WSMV-P1_ $\overline{\mathrm{A} A C} \overline{1} 3692.1$ ONMV-P1 NP 940822.1 WEqMV-P' NC 009805.1

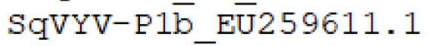
SPMMV-P1_GQG353374.1 CVYV-P1b AY578085.1 CBSV-P1_GU563327.1 CoCMoV- $\overline{\mathrm{P}} 1$ KU935732.1 BStMV-P1_ $\bar{N} P$ 734253 SCSMV-P1_KJ187047.1

\subsection{P7 possess a conserved GW motif}

The P7 sequence was analyzed for the presence of conserved domains using multiple sequence alignments on BLOSUM62 (Altschul, 1991; Henikoff, 1992). We identified a conserved GW dipeptide motif at the C-terminal region with high sequence conservation (aa 202 to 232) with other GW-containing viral RNA silencing suppressors (Fig. 4A and B). The GW motif has been shown to be involved in direct interaction with AGO proteins (El-Shami et al., 2007; Lian et al., 2009), which are the effector proteins of RISC that mediate siRNA-guided target hydrolysis. Secondary structure prediction of the GW dipeptide harboring domain showed formation of a characteristic $\beta$-sheet with GW motif toward the edge. Solubility of GW motif containing AGObinding domain of P7 was determined using Kyte-Doolittle hydropathy scale (Kyte and Doolittle, 1982) and obtained a hydropathy score of 0.5 (Fig. 4C).

\section{C}

202 NYWTPLVFNTDDEYSTGWFGDKHIEWPKSVK 257 KDGPRLVSWSKTKGTAGWEHDCHFLGTGNFS
Fig. 4. High Plains wheat mosaic virus $P 7$ harbors a conserved GW motif. (A) Homology of GW dipeptide motif (underlined) containing AGO-interacting domain of P7 with turnip crinkle virus (TCV) P38. (B) Conservation of GW dipeptide in P7 with potyviral type B P1 sequences of the family Potyviridae. TriMV: triticum mosaic virus, WSMV: wheat streak mosaic virus, ONMV: oat necrotic mottle virus, WEqMV: wheat eqlid mosaic virus, SqVYV: squash vein yellowing virus, SPMMV: sweet potato mild mottle virus, CVYV: cucumber vein yellowing virus, CBSV: cassava brown streak virus; CocMoV: coccinia mottle virus; BstMV: brome streak mosaic virus; and SCSMV: sugarcane streak mosaic virus. Similar amino acids with P7 were highlighted in green, and amino acids with similar biochemical properties were highlighted in yellow. (C) Kyte-Doolittle projection of hydropathy and Chou-Fasman prediction of secondary structure of GW containing domain of P7. The $\beta$-sheet which harbors the GW dipeptide was underlined.

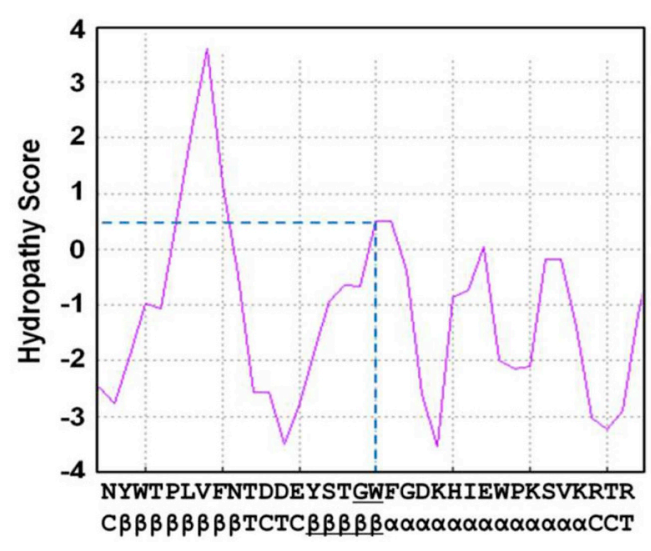




\subsection{The GW motif in HPWMoV P7 is indispensable for RNA silencing} suppression and pathogenicity enhancement

To determine the role of GW motif in P7 in ssRNA-induced local silencing, the GW motif was disrupted through W219A site-directed mutagenesis. Agroinfiltration of pCASS4-35S:P7-W219A along with 35S:ssGFP reporter into $N$. benthamiana leaves showed no detectable green fluorescence under UV light at 5 dpa (Fig. 5A). Agrobacterial constructs of wild-type P7 and empty pCASS4 were used as positive and negative controls, respectively. GFP expression and silencing were tested through Northern blot hybridization of total RNA extracted from infiltrated regions at $5 \mathrm{dpi}$. This revealed that for P7-W219A infiltrated leaf patches, GFP-specific mRNA accumulated at undetectable levels with increased accumulation of GFP-specific siRNAs compared with P7 (Fig. 5B). These results indicate that the GW motif of P7 is required for suppression of local RNA silencing.
We previously showed that chimerically inserted HPWMoV P7 or P8 enhanced pathogenicity of PVX (Gupta et al., 2018). To determine whether the GW motif plays a role in the ability of P7 to enhance pathogenicity of PVX, in vitro RNA transcripts prepared from pPVX-P7W219A construct were mechanically inoculated onto $N$. benthamiana at the 6-8 leaf stage. Plants inoculated with PVX-P7 showed severe stunting and chlorosis at 21 dpi compared with PVX-P7-W219A or PVXWT. At 28 dpi, plants inoculated with PVX-P7 showed severe apical necrosis and necrotic spots, whereas PVX-P7-W219A- or PVX-WT-inoculated plants showed milder symptoms and recovery in top leaves (Fig. 6A). RT-PCR using primers flanking the site of insertion on total RNA extracted from symptomatic leaves at 28 dpi produced expected products confirming the stability of inserted sequences in the PVX genome (Fig. 6B). RT-qPCR was performed from total RNA extracted from systemically infected leaves to determine the genomic RNA copies of PVX and found that PVX-P7-W219A accumulated similarly to wild-

\section{A}
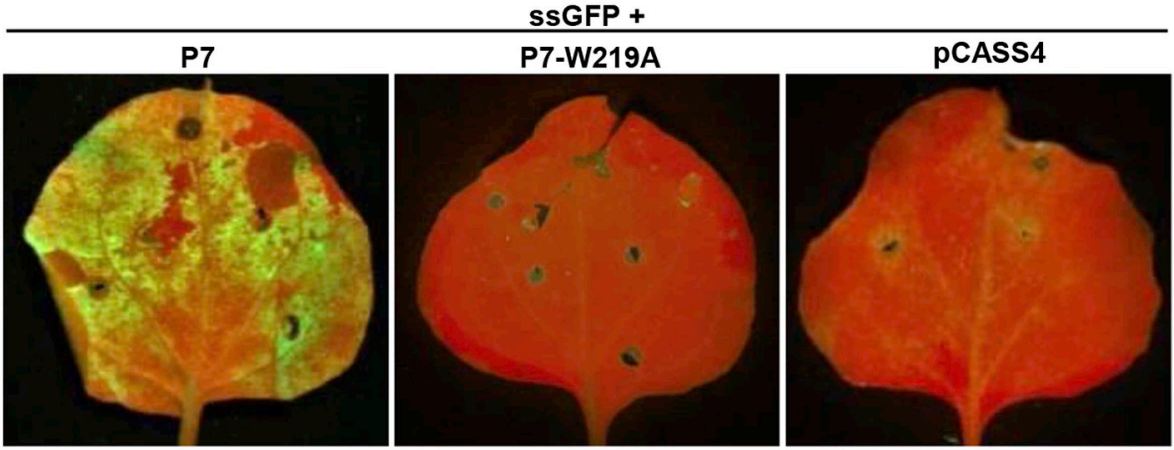

B

P7-

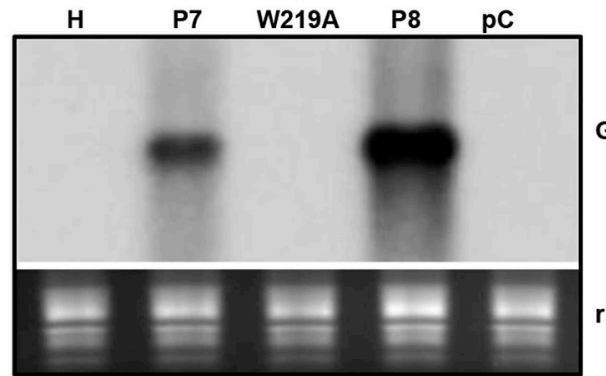

GFP mRNA

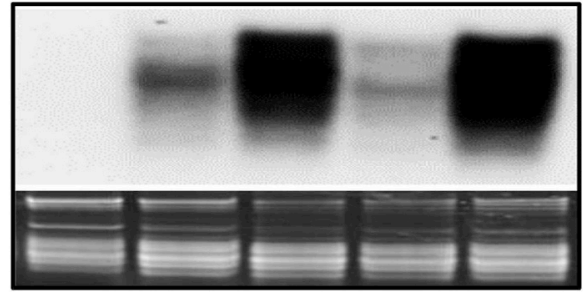

GFP SIRNA

LMW RNA
Fig. 5. Disruption of GW motif in High Plains wheat mosaic virus P7 results in loss of suppression of RNA silencing function. (A) Detection of green fluorescence under UV light in $N$. benthamiana leaves agroinfiltrated with pCASS4 constructs of 35S:P7, 35S:P7W219A or empty pCASS4 along with 35S:GFP reporter at 5 days postagroinfiltration (dpa). (B) Northern blot analyses of total RNA extracted from $N$. benthamiana leaves agroinfiltrated with pCASS435S:P7, :P7-W219A, :P8 or empty pCASS4 at 5 dpa probed with GFP-specific riboprobe to detect GFPspecific mRNA (top panel) or siRNA (bottom panel). Note the loss of green fluorescence in P7-W219A infiltrated leaf due to silencing of GFP reporter, which was confirmed by the lack of GFP-specific mRNA and increased accumulation of GFP-specific siRNAs in Northern blots. Lanes $\mathrm{H}$ and $\mathrm{pC}$ represent total RNA extracted from leaves infiltrated with buffer or empty pCASS4 vector, respectively. Ethidium bromide stained gel images below the Northern blots show the amount of total RNA loaded in corresponding lanes. 
A

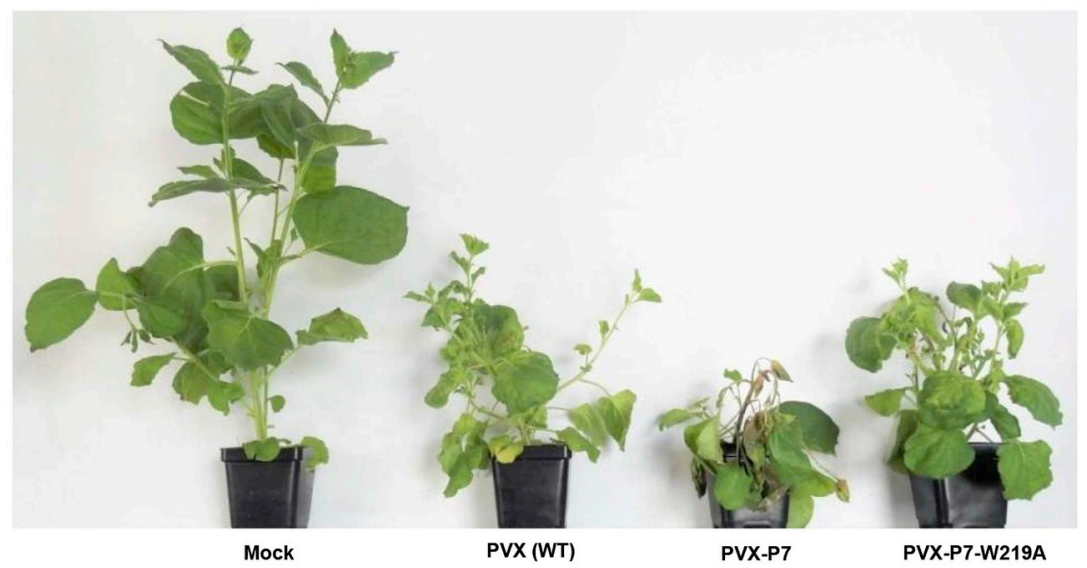

B

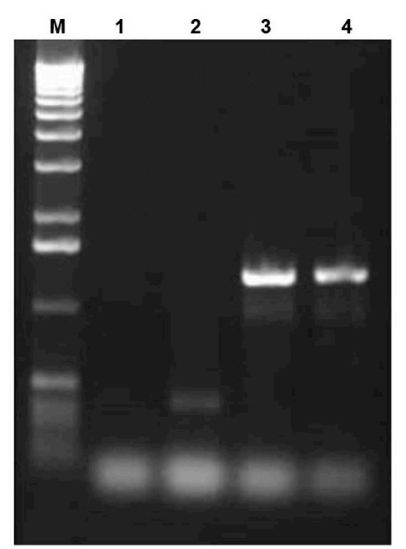

C

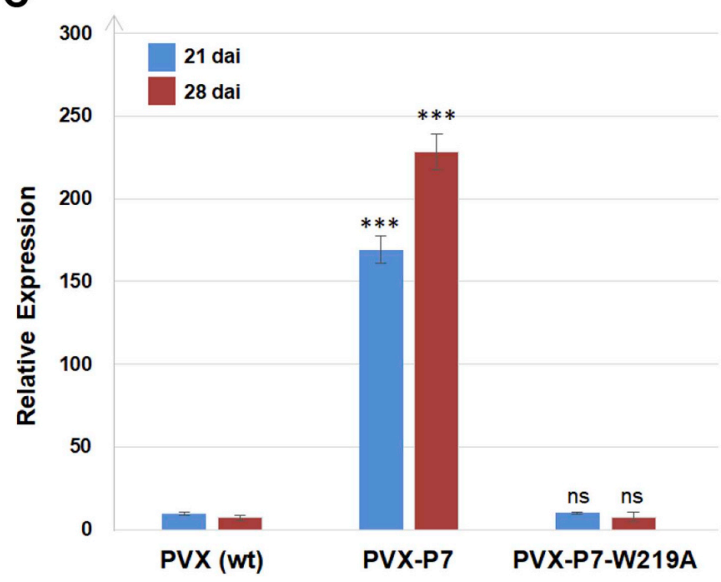

Fig. 6. The GW motif in P7 of High Plains wheat mosaic virus is required for enhancement of virulence of potato virus X (PVX). (A) Symptom phenotype of PVX-WT, PVX harboring P7, or P7-W219A in $N$. benthamiana at $28 \mathrm{dpi}$. Note the loss of ability of P7 to enhance PVX pathogenicity upon W219A mutation. Mock: buffer inoculated control. (B) RT-PCR analysis of total RNA from $N$. benthamiana plants inoculated with buffer (1), PVX-WT (2), PVX-P7 (3) or PVX-P7-W219A (4) at 28 dpi. M represents 1.0 kbp DNA ladder. (C) Real-time RT-PCR analysis of total RNA isolated from symptomatic leaves of $\mathrm{N}$. benthamiana plants inoculated with in vitro transcripts of PVX-WT, PVX-P7, or PVX-P7-W219A. Relative expression of PVX RNA was calculated by $\Delta \Delta \mathrm{Ct}$ method, following normalization using $\mathrm{Nb}$ Actin as an internal reference. Most probable differences of relative expression were calculated for each biological replicate using Student's $T$-Test. *** represents $99 \%$ confidence. Error bars indicate standard error for relative expression values between biological replicates. type PVX at 21 and 28 dpi (Fig. 6C). In contrast, PVX-P7 accumulated with an 18- and 24-fold increase compared to wild-type PVX. These data suggest that the GW motif of P7 plays a significant role in pathogenicity enhancement.

\subsection{The GW motif in P7 is required to rescue VSR-deficient WSMV}

The requirement of GW motif in P7 to rescue the VSR-deficient WSMV was examined by replacing the P1 cistron of WSMV, a suppressor of RNA silencing (Young et al., 2012), with P7-W219A in WSMV-GFP-6K1/CI(7aa) (WSMV-GFP; Tatineni et al., 2011) to generate WSMV-GFP- $\triangle$ P1-P7-W219A (Fig. 7A). Wheat seedlings inoculated at the single-leaf stage with in vitro transcripts of WSMV-GFP- $\Delta$ P1-P7W219A did not elicit local foci and systemic infection at detectable levels at 10 and $21 \mathrm{dpi}$, respectively. However, WSMV-GFP- $\Delta \mathrm{P} 1-\mathrm{P} 7$ or WSMV-GFP elicited local foci at $10 \mathrm{dpi}$, followed by systemic infection at 21 dpi (Fig. 7B). Total RNA isolated from inoculated or upper noninoculated leaves was examined by RT-PCR with primers for WSMV CP as diagnostic test for viral infection and with primers on either side of insertion for the stability of inserted sequence. RT-PCR assay revealed that wheat inoculated with WSMV-GFP or WSMV-GFP- $\triangle$ P1-P7 but not with WSMV-GFP- $\Delta$ P1-P7-W219A produced expected products (Fig. 7C). Western blot analyses of total proteins from inoculated leaves at 10 and $21 \mathrm{dpi}$ and upper noninoculated leaves at $21 \mathrm{dpi}$ showed accumulation of WSMV CP and GFP only in WSMV-GFP- or -WSMV-GFP- $\triangle$ P1-P7- inoculated samples but not in WSMV-GFP- $\triangle \mathrm{P} 1-\mathrm{P} 7-\mathrm{W} 219 \mathrm{~A}-$, WSMVGFP- $\Delta$ P1-, or mock-inoculated wheat (Fig. 7D). These data revealed that disruption of the GW motif in P7 failed to rescue the VSR-deficient WSMV; hence, the GW motif of P7 is essential for suppression of RNA silencing.

\section{Discussion}

Viruses overcome host defense against successful replication and systemic infection through counterdefensive mechanisms by encoding suppressors of RNA silencing (Carrington et al., 2001; Ding et al., 2004; Li and Ding, 2001; Scholthof et al., 1995). Most RNA viruses encode a single silencing suppressor that targets the key players of host defense to suppress intracellular (local) or intercellular (systemic) silencing, or both. However, a few viruses have evolved to encode multiple suppressors of RNA silencing (Cañizares et al., 2008; Gupta et al., 2018; Lu et al., 2004; Powers et al., 2008). Though it is unclear why a few viruses encode multiple VSRs, they may offer advantages of division of labor and diversity in the mode of action required for efficient suppression of RNA silencing.

Previously, we reported that the octapartite negative-sense RNA genome of HPWMoV encodes two suppressors of RNA silencing, P7 and P8 (Gupta et al., 2018). In this study, the mechanisms of HPWMoVencoded P7 and P8 in suppression of RNA silencing were examined. It was found that P7 protects long dsRNA from Dicer cleavage into siRNAs 
A

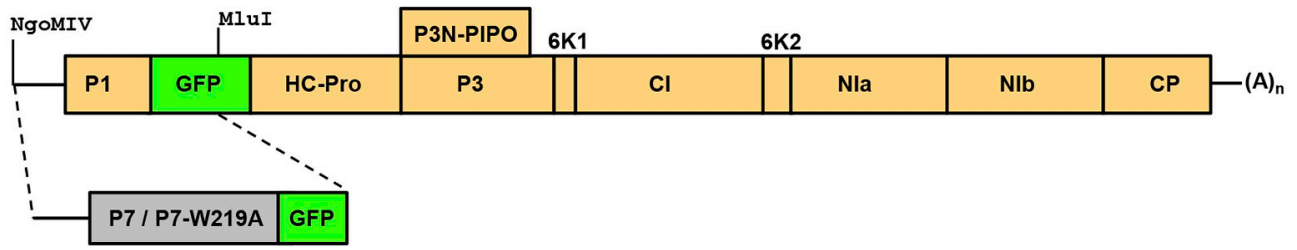

B
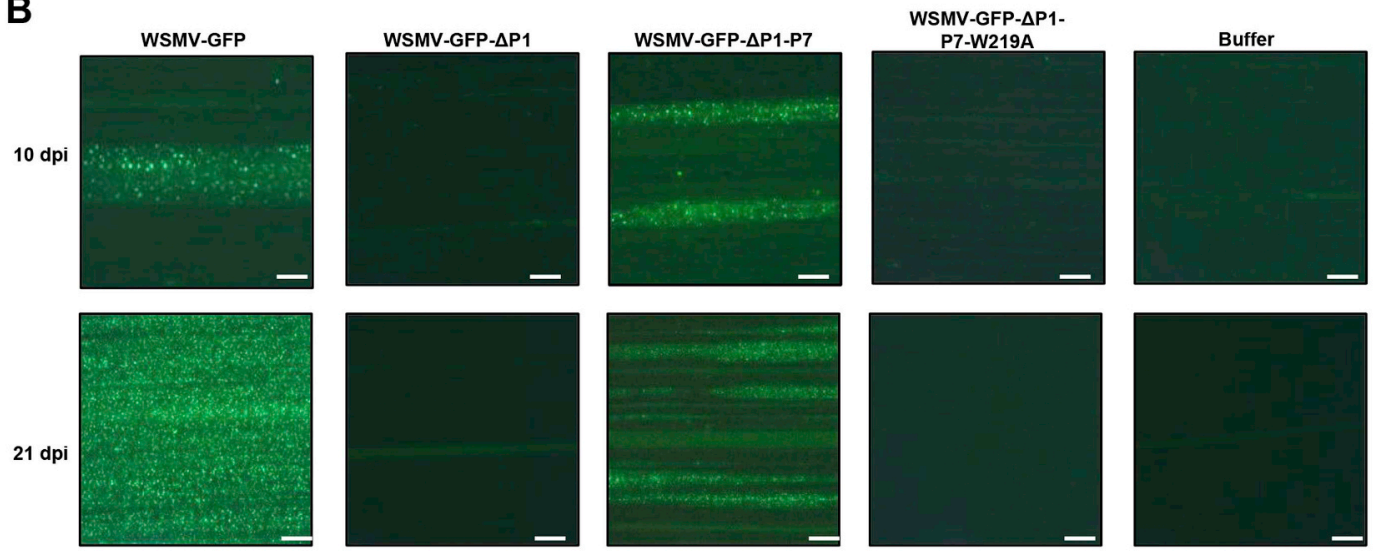

C

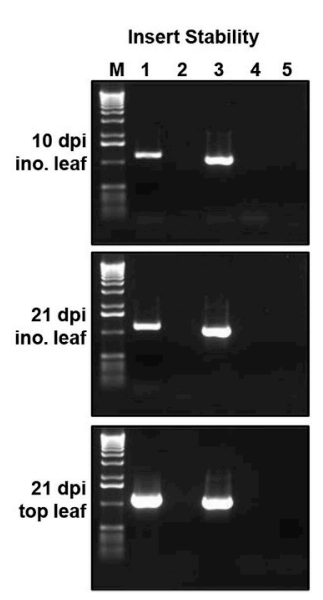

WSMV-CP

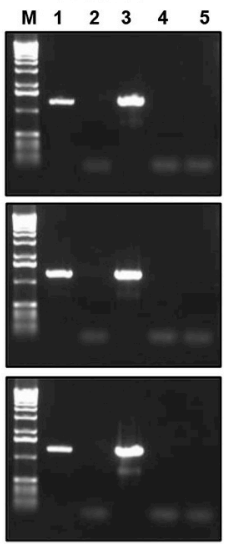

D

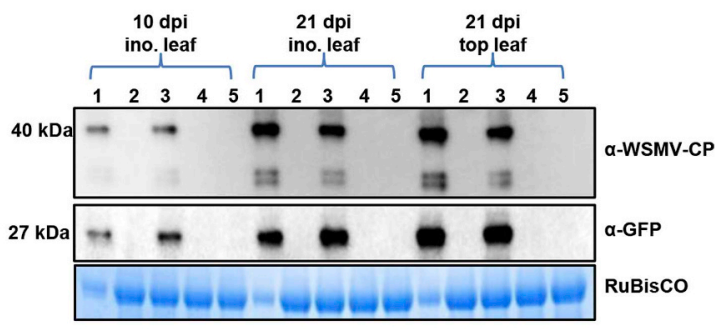

Fig. 7. The GW-motif of High Plains wheat mosaic virus (HPWMoV) P7 is required for rescue of silencing suppressor-deficient WSMV-GFP- $\Delta$ P1. (A) Schematic representation of WSMV-GFP. GFP sequence with a heptapeptide cleavage site was inserted between the P1 and HC-Pro cistrons of WSMV (Tatineni et al., 2011). The P1 cistron of WSMV replaced with P7 with a single amino acid mutation of W219A was shown in an expanded view under the genomic organization of WSMV-GFP. (B) Green fluorescent micrographs of inoculated (at $10 \mathrm{dpi}$ ) and upper noninoculated (at $21 \mathrm{dpi}$ ) leaves of wheat plants inoculated with WSMV-GFP, WSMV-GFP- $\mathrm{P} 1$, WSMV-GFP- $\triangle$ P1-P7, WSMV-GFP- $\triangle$ P1-P7-W219A, or buffer. Scale bars indicate $200 \mu \mathrm{m}$. Note that HPWMoV P7 with mutation of W219A unable to complement silencing suppressor-deficient WSMV-GFP- $\triangle \mathrm{P} 1$ for local foci or systemic infection. (C) RT-PCR assay of total RNA isolated from inoculated and upper noninoculated wheat leaves for virus infection and insert stability. Lane M, $1.0 \mathrm{kbp}$ DNA ladder. (D) Total proteins extracted from inoculated and upper noninoculated leaves were analyzed by Western blot hybridization with WSMV CP or GFP antibodies. Lower panel showing the RuBisCo protein of Coomassie Brilliant Blue R-250 stained gel for the amount of total protein loaded per well. Proteins prepared from WSMV-GFP-infected wheat leaves were loaded at 1:10 dilution compared to other samples. Lanes 1-5 in C and D represent WSMV-GFP (lane 1), WSMV-GFP- $\Delta$ P1 (lane 2), WSMV-GFP- $\Delta$ P1-P7 (lane 3), WSMV-GFP- $\Delta$ P1-P7-W219A (lane 4), and buffer (lane 5).

by forming complexes. In contrast, P8 does not prevent Dicer activity on long dsRNA as it lacks the property of binding to long dsRNA. These properties suggest that P7 is particularly significant not only in protecting replicating viral RNA but also in hampering siRNA production, RISC formation, or both. Though P7 and P8 bound to PTGS-like dssiRNAs, P8 showed stronger affinity toward ds-siRNAs compared to that of P7. Preferential binding of P8 to PTGS-like ds-siRNAs but not long dsRNA suggest that P8 potentially interferes with RISC formation and RDR-mediated ta-siRNA generation.

Binding kinetics generated through EMSA analyses of ds-siRNAs showed that P8 has stronger affinity toward 21-nt PTGS-like ds-siRNA compared with 24-nt. This observation strongly suggests that P8 specifically counters the activities of DCL4 and RDR6, which are responsible for generation of 21-nt siRNA and ta-siRNA, respectively (Henderson et al., 2006; Parent et al., 2015). Our data suggest that P8 independently suppressed dsRNA-induced systemic silencing as efficiently as P7 $+\mathrm{P} 8$, and this reinforces a role for P8 in efficient intercellular VSR activity. In Arabidopsis thaliana, DCL4 generated 21-nt siRNA and RDR6 dependent 21-nt ta-siRNA were shown to be major mobile signals of intercellular systemic silencing (Xie et al., 2005). Furthermore, Northern blot analysis of total RNA extracted from $N$. benthamiana leaves agroinfiltrated with 35S:P8 and 35S:ssGFP reporter 
at 5 dpa showed substantially reduced accumulation of 21-nt siRNA compared with 24-nt siRNA (Fig. 5B; compare lanes P7 and P8). These data suggest that higher affinity of P8 toward 21-nt siRNA facilitates efficient suppression of dsGFP-induced systemic silencing of GFP in the presence of P8 in agroinfiltrated GFP-transgenic $N$. benthamiana line $16 \mathrm{c}$ plants.

P7 lacks homology with any reported GenBank sequence (Tatineni et al., 2014); however, computational analyses of partial sequences of P7 revealed the presence of a conserved dsRBD (Fig. S1), similar to that present in potyviral type B P1 proteins (Rodamilans et al., 2013; Valli et al., 2011). The position of dsRBD in P7 is C-terminal, in contrast to the $\mathrm{N}$-terminal position in most of the P1-like proteins. This intriguing difference could be due to functional conservation across different families (Gu, 2001). Additionally, analyses of P7 sequence revealed the presence of a conserved GW dipeptide motif. The domain containing GW-motif is located downstream of dsRBD in several potyviruses (Valli et al., 2011); however, it is upstream to dsRBD in P7. On the other hand, analysis of the P8 sequence did not result in any conserved dsRNA-binding domain.

Evolution of GW motif in a viral-encoded protein is an exemplary phenomenon of adaptive evolution of viruses to mimic GW182 family of proteins that aid in executing endonuclease activity of miRISC-PIWI (Behm-Ansmant et al., 2006). It is possible that the GW containing VSRs not only establish AGO-interactions, but also to inactivate GW182 proteins through allosteric inhibition (Jin and Zhu, 2010). The GW motif is involved with direct interaction with AGO1 (El-Shami et al., 2007), AGO2 (Lian et al., 2009), and AGO4 (El-Shami et al., 2007). In A. thaliana, AGO4 was shown to acquire 24-nt siRNA during RISC formation (Zilberman et al., 2003) for siRNA directed DNA methylation in transcriptional gene silencing (Bies-Etheve et al., 2009), as well as in PTGS for anti-RNA viral defense (Bhattacharjee et al., 2009). P1 of Sweet potato mild mottle virus harbors multiple N-terminal WG/GW motifs (Giner et al., 2010); however, P7 contains a single C-terminal GW motif. Relative position of tryptophan on its $\beta$-sheet and solubility of GW containing AGO-binding domain determined through in silico analyses (Chou and Fasman, 1974; Kyte and Doolittle, 1982) suggest the presence of favorable conformity required for intermolecular P7AGO interaction. Recently, we found that the P1 protein of WSMV also contains a GW motif and disruption of this motif abolished the suppression of RNA silencing activity of P1 (Gupta and Tatineni, 2019a).

Disruption of GW motif in P7 through a W219A mutation resulted in failure to suppress RNA silencing triggered by a GFP reporter transgene, indicating that the GW motif is required for VSR activity. Furthermore, expression of P7-W219A through PVX showed no significant increase in pathogenicity of PVX, demonstrating the inability of P7-W219A to enhance pathogenicity. We previously showed that P7 rescued a VSRdeficient WSMV by complementing the functions of WSMV P1, a suppressor of RNA silencing (Gupta et al., 2018; Young et al., 2012). However, WSMV-GFP- $\Delta$ P1-P7-W219A failed to form local foci or establish systemic infection in wheat, indicating that P7 with W129A mutation failed to rescue the silencing-suppressor deficient WSMV. In total, these results suggest that the GW motif play a key role in the ability of P7 to execute VSR functions in experimental non-host $N$. benthamiana as well as in its natural host wheat.

Taken together, the two suppressors of RNA silencing proteins encoded by HPWMoV (P7 and P8) employ distinct mechanisms to suppress the host defense mechanisms, demonstrating efficient division of labor. A continuum of virus-host interactions results in viral infection eliciting host-defensive RNA silencing that in turn triggers virus-encoded counterdefensive suppression of RNA silencing. Understanding the key strategies viruses use to overcome the natural antiviral defenses employed by plants could facilitate the development of novel strategies for the management of economically important plant viruses. Several viruses employ efficient mechanisms against RNA silencing, but it is significant to understand VSRs to the level of domains or amino acids that modulate host defenses. Studying counterdefense mechanisms strengthens our understanding of virus-host interactions, but it also supports integrated approaches of disease management.

\section{Acknowledgments}

This work was funded by USDA ARS CRIS (5440-21000-033-00D). USDA is an equal opportunity provider and employer. Mention of trade names or commercial products in this publication is solely for the purpose of providing specific information and does not imply recommendation or endorsement by the U.S. Department of Agriculture.

\section{Appendix A. Supplementary data}

Supplementary data to this article can be found online at https:// doi.org/10.1016/j.virol.2019.06.011.

\section{References}

El-Shami, M., Pontier, D., Lahmy, S., Braun, L., Picart, C., Vega, D., Hakimi, M.A., Jacobsen, S.E., Cooke, R., Lagrange, T., 2007. Reiterated WG/GW motifs form functionally and evolutionarily conserved ARGONAUTE-binding platforms in RNAi-related components. Genes Dev. 21, 2539-2544.

Altschul, S.F., 1991. Amino acid substitution matrices from an information theoretic perspective. J. Mol. Biol. 219, 555-565.

Aqil, M., Naqvi, A.R., Bano, A.S., Jameel, S., 2013. The HIV-1 Nef protein binds argonaute- 2 and functions as a viral suppressor of RNA interference. PLoS One 8 e74472.

Baulcombe, D., 2004. RNA silencing in plants. Nature 43, 356-363.

Behm-Ansmant, I., Rehwinkel, J., Doerks, T., Stark, A., Bork, P., Izaurralde, E., 2006. mRNA degradation by miRNAs and GW182 requires both CCR4:NOT deadenylase and DCP1:DCP2 decapping complexes. Genes Dev. 20, 1885-1898.

Berry, B., Deddouche, S., Kirschner, D., Imler, J.-L., Antoniewski, C., 2009. Viral suppressors of RNA silencing hinder exogenous and endogenous small RNA pathways in Drosophila. PLoS One 4 (6), e5866.

Bhattacharjee, S., Zamora, A., Azhar, M.T., Sacco, M.A., Lambert, L.H., Moffett, P., 2009. Virus resistance induced by NB-LRR proteins involves Argonaute4-dependent translational control. Plant J. 58, 940-951.

Bies-Etheve, N., Pontier, D., Lahmy, S., Picart, C., Vega, D., Cooke, R., Lagrange, T., 2009. RNA-directed DNA methylation requires an AGO4-interacting member of the SPT5 elongation factor family. EMBO Rep. 10, 649-654.

Bisswanger, H., 2014. Enzyme assays. Perspect. Sci. 1, 41-55.

Cañizares, M.C., Navas-Castillo, J., Moriones, E., 2008. Multiple suppressors of RNA silencing encoded by both genomic RNAs of the crinivirus, Tomato chlorosis virus. Virology 379, 168-174.

Carrington, J.C., Kasschau, K.D., Johansen, L.K., 2001. Activation and suppression of RNA silencing by plant viruses. Virology 281, 1-5.

Chapman, S., Kavanagh, T., Baulcombe, D.C., 1992. Potato virus X as a vector for gene expression in plants. Plant J. 2, 549-557.

Chen, H.Y., Yang, J., Lin, C., Yuan, Y.A., 2008. Structural basis for RNA-silencing suppression by Tomato aspermy virus protein 2b. EMBO Rep. 9, 754-760.

Chiu, M.H., Chen, I.H., Baulcombe, D.C., Tsai, C.H., 2010. The silencing suppressor P25 of Potato virus $\mathrm{X}$ interacts with Argonaute 1 and mediates its degradation through the proteasome pathway. Mol. Plant Pathol. 11, 641-649.

Choi, I.R., French, R., Hein, G.L., Stenger, D.C., 1999. Fully biologically active in vitro transcripts of the eriophyid mite-transmitted wheat streak mosaic tritimovirus. Phytopathology 89, 1182-1185.

Chou, P.Y., Fasman, G.D., 1974. Conformational parameters for amino acids in helical, $\beta$ sheet, and random coil regions calculated from proteins. Biochemistry 13, 211-222.

Covey, S.N., Al-Kaff, N., Lángara, A., Turner, D.S., 1997. Plants combat infection by gene silencing. Nature 385, 781-782.

Cronin, S., Verchot, J., Haldeman-Cahill, R., Schaad, M.C., Carrington, J.C., 1995. Longdistance movement factor: a transport function of the potyvirus helper component proteinase. Plant Cell 7, 549-559.

Csorba, T., Lózsa, R., Hutvágner, G., Burgyán, J., 2010. Polerovirus protein P0 prevents the assembly of small RNA-containing RISC complexes and leads to degradation of ARGONAUTE1. Plant J. 62, 463-472.

Csorba, T., Kontra, L., Burgyan, J., 2015. Viral silencing suppressors: tools forged to finetune host-pathogen coexistence. Virology 479-480, 85-103.

Diaz-Pendon, J.A., Li, F., Li, W.X., Ding, S.W., 2007. Suppression of antiviral silencing by cucumber mosaic virus $2 \mathrm{~b}$ protein in Arabidopsis is associated with drastically reduced accumulation of three classes of viral small interfering RNAs. Plant Cell 19 2053-2063.

Ding, S.W., Voinnet, O., 2007. Antiviral immunity directed by small RNAs. Cell 130, 413-426.

Ding, B., Li, Q., Nguyen, L., Palukaitis, P., Lucas, W.J., 1995. Cucumber mosaic virus 3a protein potentiates cell-to-cell trafficking of CMV RNA in tobacco plants. Virology 207, 345-353.

Ding, S.W., Li, H., Lu, R., Li, F., Li, W.X., 2004. RNA silencing: a conserved antiviral immunity of plants and animals. Virus Res. 102, 109-115.

Dunoyer, P., Herzog, E., Hemmer, O., Ritzenthaler, C., Fritsch, C., 2001. Peanut clump virus RNA-1-encoded P15 regulates viral RNA accumulation but is not abundant at 
viral RNA replication sites. J. Virol. 75, 1941-1948.

Fire, A., Xu, S., Montgomery, M.K., Kostas, S.A., Driver, S.E., Mello, C.C., 1998. Potent and specific genetic interference by double-stranded RNA in Caenorhabditis elegans. Nature 391, 806-811.

Giner, A., Lakatos, L., García-Chapa, M., López-Moya, J.J., Burgyán, J., 2010. Viral protein inhibits RISC activity by argonaute binding through conserved WG/GW motifs. PLoS Pathog. 6 e1000996.

Gu, X., 2001. Maximum-likelihood approach for gene family evolution under functional divergence. Mol. Biol. Evol. 18, 453-464.

Guo, H., Song, X., Xie, C., Huo, Y., Zhang, F., Chen, X., Geng, Y., Fang, R., 2013. Rice yellow stunt rhabdovirus protein 6 suppresses systemic RNA silencing by blocking RDR6-mediated secondary siRNA synthesis. Mol. Plant Microbe Interact. 26, 927-936.

Gupta, A.K., Tatineni, S., 2019a. Wheat streak mosaic virus P1 binds to dsRNAs without size and sequence specificity and a GW motif is crucial for suppression of RNA silencing. Viruses 11,472

Gupta, A.K., Tatineni, S., 2019b. RNA silencing suppression mechanisms of Triticum mosaic virus P1: dsRNA binding property and mapping functional motifs. Virus Res (in press).

Gupta, A.K., Hein, G.L., Graybosch, R.A., Tatineni, S., 2018. Octapartite negative-sense RNA genome of High Plains wheat mosaic virus encodes two suppressors of RNA silencing. Virology 518, 152-162.

Hamilton, A.J., Baulcombe, D.C., 1999. A species of small antisense RNA in posttranscriptional gene silencing in plants. Science 286, 950-952.

Heffler, M.A., Walters, R.D., Kugel, J.F., 2012. Using electrophoretic mobility shift assays to measure equilibrium dissociation constants: GAL4-p53 binding DNA as a model system. Biochem. Mol. Biol. Educ. 40, 383-387.

Henderson, I.R., Zhang, X., Lu, C., Johnson, L., Meyers, B.C., Green, P.J., Jacobsen, S.E., 2006. Dissecting Arabidopsis thaliana DICER function in small RNA processing, gene silencing and DNA methylation patterning. Nat. Genet. 38, 721-725.

Henikoff, J.G., 1992. Amino acid substitution matrices from protein blocks. Proc. Natl Acad. Sci. U.S.A. 89, 10915-10919.

Iki, T., Tschopp, M.A., Voinnet, O., 2017. Biochemical and genetic functional dissection of the P38 viral suppressor of RNA silencing. RNA 23, 639-654.

Iwasaki, S., Kobayashi, M., Yoda, M., Sakaguchi, Y., Katsuma, S., Suzuki, T., Tomari, Y., 2010. Hsc70/Hsp90 chaperone machinery mediates ATP-dependent RISC loading of small RNA duplexes. Mol. Cell 39, 292-299.

Jamous, R.M., Boonrod, K., Fuellgrabe, M.W., Ali-Shtayeh, M.S., Krczal, G., Wassenegger, M., 2011. The helper component-proteinase of the Zucchini yellow mosaic virus inhibits the Hua Enhancer 1 methyltransferase activity in vitro. J. Gen. Virol. 92, $2222-2226$.

Jin, H., Zhu, J.K., 2010. A viral suppressor protein inhibits host RNA silencing by hooking up with Argonautes. Genes Dev. 24, 853-856.

Ketting, R.F., Fischer, S.E., Bernstein, E., Sijen, T., Hannon, G.J., Plasterk, R.H.A., 2001. Dicer functions in RNA interference and in synthesis of small RNA involved in developmental timing in Caenorhabditis elegans. Genes Dev. 15, 2654-2659.

Kyte, J., Doolittle, R.F., 1982. A simple method for displaying the hydropathic character of a protein. J. Mol. Biol. 157, 105-132.

Lacombe, S., Bangratz, M., Vignols, F., Brugidou, C., 2010. The rice yellow mottle virus P1 protein exhibits dual functions to suppress and activate gene silencing. Plant J. Cell Mol. Biol. 61, 371-382.

Lakatos, L., Szittya, G., Silhavy, D., Burgyán, J., 2004. Molecular mechanism of RNA silencing suppression mediated by 19 protein of tombusviruses. EMBO J. 23, 876-884.

Landeo-Ríos, Y., Navas-Castillo, J., Moriones, E., Cañizares, M.C., 2016. The p22 RNA silencing suppressor of the crinivirus Tomato chlorosis virus preferentially binds long dsRNAs preventing them from cleavage. Virology 488, 129-136.

Li, W.X., Ding, S.W., 2001. Viral suppressors of RNA silencing. Curr. Opin. Biotechnol. 12, 150-154.

Li, F., Ding, S.W., 2006. Virus counterdefense: diverse strategies for evading the RNAsilencing immunity. Annu. Rev. Microbiol. 60, 503-531.

Lian, S.L., Li, S., Abadal, G.X., Pauley, B.A., Fritzler, M.J., Chan, E.K., 2009. The Cterminal half of human Ago 2 binds to multiple GW-rich regions of GW182 and requires GW182 to mediate silencing. RNA 15, 804-813.

Lingel, A., Simon, B., Izaurralde, E., Sattler, M., 2003. Structure and nucleic-acid binding of the Drosophila Argonaute 2 PAZ domain. Nature 426, 465-469.

Lingel, A., Simon, B., Izaurralde, E., Sattler, M., 2005. The structure of the flock house virus B2 protein, a viral suppressor of RNA interference, shows a novel mode of double-stranded RNA recognition. EMBO Rep. 6, 1149-1155.

Liu, J., Shi, G.P., Zhang, W.Q.,, Zhang, G.R.,, Xu, W.H., 2006. Cathepsin L function in insect moulting: molecular cloning and functional analysis in cotton bollworm, Helicoverpa armigera. Insect Mol. Biol. 15, 823-834.

Lu, R., Folimonov, A., Shintaku, M., Li, W.X., Falk, B.W., Dawson, W.O., Ding, S.W., 2004. Three distinct suppressors of RNA silencing encoded by a 20-kb viral RNA genome. Proc. Natl. Acad. Sci. U.S.A. 101, 15742-15747.

Mann, K.S., Johnson, K.N., Dietzgen, R.G., 2015. Cytorhabdovirus phosphoprotein shows RNA silencing suppressor activity in plants, but not in insect cells. Virology 476, 413-418.

Mann, K.S., Johnson, K.N., Carroll, B.J., Dietzgen, R.G., 2016. Cytorhabdovirus P protein suppresses RISC-mediated cleavage and RNA silencing amplification in planta. Virology 490, 27-40.
Melnyk, C.W., Molnar, A., Baulcombe, D.C., 2011. Intercellular and systemic movement of RNA silencing signals. EMBO J. 30, 3553-3563.

Mérai, Z., Kerényi, Z., Molnár, A., Barta, E., Válóczi, A., Bisztray, G., Havelda, Z., Burgyán, J., Silhavy, D., 2005. Aureusvirus P14 is an efficient RNA silencing suppressor that binds double-stranded RNAs without size specificity. J. Virol. 79, 7217-7226.

Mérai, Z., Kerényi, Z., Kertész, S., Magna, M., Lakatos, L., Silhavy, D., 2006. Doublestranded RNA binding may be a general plant RNA viral strategy to suppress RNA silencing. J. Virol. 80, 5747-5756.

Parent, J.-S., Bouteiller, N., Elmayan, T., Vaucheret, H., 2015. Respective contributions of Arabidopsis DCL2 and DCL4 to RNA silencing. Plant J. 81, 223-232.

Powers, J.G., Sit, T.L., Heinsohn, C., George, C.G., Kim, K.-H., Lommel, S.A., 2008. The red clover necrotic mosaic virus RNA-2 encoded movement protein is a second suppressor of RNA silencing. Virology 381, 277-286.

Qian, S., Zhong, X., Yu, L., Ding, B., de Haan, P., Boris-Lawrie, K., 2009. HIV-1 Tat RNA silencing suppressor activity is conserved across kingdoms and counteracts translational repression of HIV-1. Proc. Natl. Acad. Sci. U.S.A. 106, 605-610.

Qu, F., Ren, T., Morris, T.J., 2003. The coat protein of turnip crinkle virus suppresses posttranscriptional gene silencing at an early initiation step. J. Virol. 77, 511-522.

Rand, T.A., Petersen, S., Du, F., Wang, X., 2005. Argonaute2 cleaves the anti-guide strand of siRNA during RISC activation. Cell 123, 621-629.

Ratcliff, F., Harrison, B.D., Baulcombe, D.C., 1997. A similarity between viral defense and gene silencing in plants. Science 276, 1558-1560.

Reed, J.C., Kasschau, K.D., Prokhnevsky, A.I., Gopinath, K., Pogue, G.P., Carrington, J.C., Dolja, V.V., 2003. Suppressor of RNA silencing encoded by beet yellows virus. Virology 306, 203-209.

Rivas, F.V., Tolia, N.H., Song, J.J., Aragon, J.P., Liu, J., Hannon, G.J., Joshua-Tor, L., 2005. Purified Argonaute 2 and an siRNA form recombinant human RISC. Nat. Struct. Mol. Biol. 12, 340-349.

Rodamilans, B., Valli, A., Gacría, J.A., 2013. Mechanistic divergence between P1 proteases of the family Potyviridae. J. Gen. Virol. 94, 1407-1414.

Samuel, G.H., Wiley, M.R., Badawi, A., Adelman, Z.N., Myles, K.M., 2016. Yellow fever virus capsid protein is a potent suppressor of RNA silencing that binds doublestranded RNA. Proc. Natl. Acad. Sci. U.S.A. 113, 13863-13868.

Schneider, C.A., Rasband, W.S., Eliceiri, K.W., 2012. NIH Image to ImageJ: 25 years of image analysis. Nat. Methods 9, 671-675.

Schnettler, E., Hemmes, H., Huismann, R., Goldbach, R., Prins, M., Kormelink, R., 2010 Diverging affinity of tospovirus RNA silencing suppressor proteins, NSs, for various RNA duplex molecules. J. Virol. 84, 11542-11554.

Scholthof, H.B., Scholthof, K.B., Kikkert, M., Jackson, A.O., 1995. Tomato bushy stunt virus spread is regulated by two nested genes that function in cell-to-cell movement and host-dependent systemic invasion. Virology 213, 425-438.

Schwarz, D.S., Hutvágner, G., Du, T., Xu, Z., Aronin, N., Zamore, P.D., 2003. Asymmetry in the assembly of the RNAi enzyme complex. Cell 115, 199-208.

Sijen, T., Fleenor, J., Simmer, F., Thijssen, K.L., Parrish, S., Timmons, L., Plasterk, R.H., Fire, A., 2001. On the role of RNA amplification in dsRNA-triggered gene silencing. Cell 107, 465-476.

Silhavy, D., Molnár, A., Lucioli, A., Szittya, G., Hornyik, C., Tavazza, M., Burgyán, J., 2002. A viral protein suppresses RNA silencing and binds silencing-generated, 21- to 25-nucleotide double-stranded RNAs. EMBO J. 21, 3070-3080.

Song, J.J., Smith, S.K., Hannon, G.J., Joshua-Tor, L., 2004. Crystal structure of Argonaute and its implications for RISC slicer activity. Science 305, 1434-1437.

Takeda, A., Tsukuda, M., Mizumoto, H., Okamoto, K., Kaido, M., Mise, K., Okuno, T., 2005. A plant RNA virus suppresses RNA silencing through viral RNA replication. EMBO J. 24, 3147-3157.

Tatineni, S., McMechan, J.A., Hein, G.L., French, R., 2011. Efficient and stable expression of GFP through Wheat streak mosaic virus-based vectors in cereal hosts using a range of cleavage sites: formation of dense fluorescent aggregates for sensitive virus tracking. Virology 410, 268-281.

Tatineni, S., Qu, F., Li, R., Morris, T.J., French, R., 2012. Triticum mosaic poacevirus enlists P1 rather than HC-Pro to suppress RNA silencing-mediated host defense. Virology 433, 104-115.

Tatineni, S., McMechan, A.J., Wosula, E.N., Wegulo, S.N., Graybosch, R.A., French, R., Hein, G.L., 2014. An eriophyid mite-transmitted plant virus contains eight genomic RNA segments with unusual heterogeneity in the nucleocapsid protein. J. Virol. 88, 11834-11845.

Tatineni, S., Elowsky, C., Graybosch, R.A., 2017. Wheat streak mosaic virus coat protein deletion mutants elicit more severe symptoms than wild-type virus in multiple cereal hosts. Mol. Plant Microbe Interact. 30, 974-983.

Tian, Y., Simanshu, D.K., Ma, J.B., Patel, D.J., 2011. Structural basis for piRNA 2'-Omethylated 3'-end recognition by Piwi PAZ (Piwi/Argonaute/Zwille) domains. Proc. Natl. Acad. Sci. U.S.A. 108, 903-910.

Valli, A., Oliveros, J.C., Molnar, A., Baulcombe, D.C., Garcia, J.A., 2011. The specific binding to 21-nt double-stranded RNAs is crucial for the anti-silencing activity of cucumber vein yellowing virus P1b and perturbs endogenous small RNA populations. RNA 17, 1148-1158.

Vogler, H., Akbergenov, R., Shivaprasad, P.V., Dang, V., Fasler, M., Kwon, M.O., Zhanybekova, S., Hohn, T., Heinlein, M., 2007. Modification of small RNAs associated with suppression of RNA silencing by tobamovirus replicase protein. J. Virol. 81, 10379-10388.

Xie, Z., Allen, E., Wilken, A., Carrington, J.C., 2005. DICER-LIKE 4 functions in trans- 
acting small interfering RNA biogenesis and vegetative phase change in Arabidopsis thaliana. Proc. Natl. Acad. Sci. U.S.A. 102, 12984-12989.

Xiong, R., Wu, J., Zhou, Y., Zhou, X., 2009. Characterization and subcellular localization of an RNA silencing suppressor encoded by Rice stripe tenuivirus. Virology 387, $29-40$.

Yang, Z., Ebright, Y.W., Yu, B., Chen, X., 2006. HEN1 recognizes 21-24 nt small RNA duplexes and deposits a methyl group onto the 2 ' $\mathrm{OH}$ of the 3 ' terminal nucleotide. Nucleic Acids Res. 34, 667-675.
Yang, X., Tan, S.H., Teh, Y.J., Yuan, Y.A., 2011. Structural implications into dsRNA binding and RNA silencing suppression by NS3 protein of Rice Hoja Blanca Tenuivirus. RNA 17, 903-911.

Young, B.A., Stenger, D.C., Qu, F., Morris, T.J., Tatineni, S., French, R., 2012. Tritimovirus P1 functions as a suppressor of RNA silencing and an enhancer of disease symptoms. Virus Res. 163, 672-677.

Zilberman, D., Cao, X., Jacobsen, S.E., 2003. ARGONAUTE4 control of locus-specific siRNA accumulation and DNA and histone methylation. Science 299, 716-719. 